\title{
The incidence of anaerobes in the sputum of patients with cystic fibrosis
}

\author{
LINDA A. JEWES and R. C. SPENCER
}

Department of Bacteriology, Royal Hallamshire Hospital, Glossop Road, Sheffield S10 2JF

\begin{abstract}
Summary. The number of anaerobes in selected sputum samples from patients with cystic fibrosis (CF) was investigated. When cultured by a semi-quantitative method, $26(23.85 \%)$ of 109 sputum specimens from $21 \mathrm{CF}$ patients contained $>10^{5} \mathrm{cfu}$ of anaerobic organisms $/ \mathrm{ml}$. Nine $(42.7 \%)$ of the 21 patients produced sputum containing such concentrations of anaerobes on at least one occasion. Anaerobes were isolated from repeated sputum specimens from five patients. The anaerobes most often isolated were Bacteroides disiens, pigmented Bacteroides spp. and anaerobic grampositive cocci. Anaerobes were isolated more often from sputum liquefied by sonication than from unliquefied sputum, suggesting that they were unlikely to be oropharyngeal contaminants.
\end{abstract}

\section{Introduction}

Cystic fibrosis (CF), the commonest genetically inherited disease among Caucasian children, is characterised by abnormal bronchial mucus secretion leading to chronic bacterial pulmonary infection and progressive respiratory dysfunction which is nearly always fatal. Progression of the pulmonary disease may be slowed by intensive physiotherapy and treatment of acute exacerbations of infection with antimicrobial agents directed against the pathogens most frequently isolated from CF patients, i.e., in the early years Staphylococcus aureus and Haemophilus influenzae with Pseudomonas aeruginosa as a later acquisition (Smith, 1986). However, other organisms have been associated with infection in CF, including Streptococcus pneumoniae, enterobacteria, viruses, fungi, mycoplasmas and chlamydiae.

In recent years, several workers have assessed the role of anaerobes in pulmonary infection in CF. Brook and Fink (1983) and Thomassen et al. (1984) reported the isolation of anaerobes from transtracheal and thoracotomy specimens (lung biopsies and parenchymal aspirates) from $\mathrm{CF}$ patients. The importance of anaerobes in other types of pulmonary infection in children is well recognised, especially in the USA (Bartlett and Finegold, 1974; Brook and Finegold, 1980). In the present study, the number of anaerobes in the sputum of $\mathrm{CF}$ patients was measured by use of a semi-quantitative method, similar to that described by Thomassen $e t$ al. (1984).

Received 28 Nov. 1988; revised version accepted 24 Oct. 1989.

\section{Materials and methods}

\section{Specimen collection}

During 7 months, 109 good quality sputum specimens were obtained from 21 CF patients, aged 5-17 years (mean 5.2 specimens/patient, range 1-17 specimens/ patient). All specimens were obtained under the supervision of a physiotherapist at routine outpatient attendances or during admission for treatment of acute exacerbations of infection. Specimens from inpatients were obtained on admission and twice weekly thereafter.

\section{Bacteriological examination}

Macroscopically non-purulent specimens were discarded. The remainder were examined as soon as possible, usually between $30 \mathrm{~min}$ and $3 \mathrm{~h}$ after collection. By examining a gram-stained film, the number of pus cells (polymorphonuclear leucocytes) and epithelial cells in each specimen was determined. Cultures were made from specimens with $>10$ pus cells and less than five epithelial cells per high power field $(x 400)$ only. This resulted in a total of 109 specimens being cultured.

Cultures were made initially from untreated, undiluted samples, selecting the most purulent part of the specimen. The specimens were then liquefied by sonication, with an MSE sonicator (Scientific Instruments, Sussex Manor Park, Crawley, West Sussex) for $10 \mathrm{~s}$ at an amplitude of $12 \mu \mathrm{m}$ and diluted 1 in 2,1 in 20 and 1 in 100 in normal saline. Cultures were then made from each of these dilutions by seeding by standard streaking one loopful $(0.01 \mathrm{ml})$ on to a plate of Fastidious Anaerobe Agar (Lab M, Topley House, PO Box 19, Bury, Lancs) supplemented with lysed horse blood $5 \%$. A metronidazole 5- $\mu \mathrm{g}$ disk was placed in the inoculum well and the plates were incubated anaerobically for 7 days at $37^{\circ} \mathrm{C}$ in an 
atmosphere of $\mathrm{N}_{2} 80 \%, \mathrm{CO}_{2} 10 \%$, and $\mathrm{H}_{2} 10 \%$ in an anaerobic jar.

Anaerobes were recognised by a zone of inhibition around the metronidazole disk. Only anaerobes growing from the 1 in 100 dilution (indicating concentrations of $>10^{5} \mathrm{cfu} / \mathrm{ml}$ of sputum) were considered to be of possible significance. Anaerobes growing only from the lower dilutions were disregarded as probable oral contaminants.

Gram-negative anaerobic bacilli were identified by tests of dye and bile tolerance, pigment production, antibiotic resistance, sugar fermentation, indole production, gelatin digestion and aesculin hydrolysis (Duerden et al., 1980). Anaerobic gram-positive cocci were not identified further and anaerobic gram-negative cocci were assumed to be veillonellae. Anaerobic gram-positive bacilli were not isolated.

\section{Results}

Anaerobes were isolated in numbers greater than $10^{5} \mathrm{cfu} / \mathrm{ml}$ from $26(23.85 \%)$ of the 109 specimens. They were isolated from nine $(42.7 \%)$ of the 21 patients on at least one occasion.

The anaerobic species isolated are shown in table I. Those most commonly isolated were Bacteroides disiens and anaerobic gram-positive cocci (eight isolates each). Pigmented Bacteroides spp. were found in seven samples ( $B$. intermedius, two; $B$. asaccharolyticus, three; unidentified, two). One specimen contained two types of anaerobe $(B$. asaccharolyticus and an anaerobic coccus) and one contained three $(B$. disiens, $B$. ureolyticus and a veillonella).

Of the 26 specimens containing anaerobes in numbers greater than $10^{5} \mathrm{cfu} / \mathrm{ml}, 16$ were taken during acute exacerbations and 10 during routine outpatient attendances. Four or more specimens were taken from only 10 of the 21 patients.

Table I. Anaerobes isolated from the sputum of CF patients

\begin{tabular}{lcc} 
Organism & $\begin{array}{c}\text { Number of } \\
\text { isolates }\end{array}$ & $\begin{array}{c}\text { Number of } \\
\text { patients }\end{array}$ \\
\hline B. disiens & 8 & 3 \\
B. intermedius & 2 & 1 \\
B. ureolyticus & 2 & 2 \\
$\begin{array}{l}\text { B. oralis } \\
\text { B. asaccharolyticus }\end{array}$ & 2 & 2 \\
Unidentified pigmented Bacter- & 3 & 2 \\
oides spp. & 2 & 1 \\
Anaerobic gram-positive cocci & 8 & 5 \\
Veillonellae & 2 & 2 \\
Total & $29 *$ & \\
\hline
\end{tabular}

*One specimen yielded three different isolates and another, two.
Anaerobes in numbers greater than $10^{5} \mathrm{cfu} / \mathrm{ml}$ were isolated from repeated specimens from five of the 10 , and the same Bacteroides spp. was present in more than one specimen from three of the five (table II).

It was particularly noteworthy that anaerobes were not isolated readily from undiluted, unliquefied sputum. Of the 29 isolates of anaerobes from 26 sputa, only four $(13.8 \%)$ grew heavily from undiluted sputum, as well as from sputum diluted up to 1 in 100 . Thirteen $(44.8 \%)$ of the isolates were not isolated from undiluted specimens; they grew on plates inoculated with the sonicated and diluted specimens only. A further 12 isolates $(41.3 \%)$ grew scantily in cultures of undiluted sputum, but more profusely when the specimens had been liquefied and diluted.

\section{Discussion}

Most studies of anaerobic pulmonary infection have been made in the USA, where examination of sputum collected by transtracheal puncture or at bronchoscopy have shown rates of such infection ranging from 21 to $35 \%$ for both community and hospital acquired pneumonia (Ries et al., 1974; Pollack et al., 1983; Bartlett et al., 1986). In the UK, anaerobes are considered to be of significance in certain pulmonary conditions only, such as bronchiectasis, lung abscess and aspiration pneumonia. Because bronchiectasis occurs in $\mathrm{CF}$, the presence of anaerobes in the lungs of such patients is to be expected. Thus, Brook and Fink (1983) isolated anaerobes from four of six transtracheal aspirates from patients with CF. Thomassen et al. (1984) found anaerobes in numbers greater than $10^{5} \mathrm{cfu} / \mathrm{ml}$ in two of 10 such patients from whom both sputum and thoracotomy specimens were cultured anaerobically. Using a semi-quantitative technique, they found excellent correlation between the numbers of anaerobes isolated from both types of specimen. Based on the principle that bacterial infections of the lower respiratory tract are almost invariably associated with bacterial concentrations greater than $10^{5} \mathrm{cfu} / \mathrm{ml}$ of secretions, other workers also have found that quantitative culture minimises false positive results from oral contamination in the diagnosis of anaerobic lung infection (Bartlett and Finegold, 1978; Winterbauer et al., 1983; Winterbauer, 1985).

In the present study, the likelihood that the anaerobes cultured were from the mouth was reduced by culturing only specimens minimally contaminated with saliva, as assessed by examination of a gram-stained film, and by quantitative 
Table II. Patients from whom anaerobes were isolated more than once

\begin{tabular}{|c|c|c|c|c|c|}
\hline \multirow[b]{2}{*}{$\begin{array}{l}\text { Patient } \\
\text { no. }\end{array}$} & \multirow[b]{2}{*}{ Age } & \multicolumn{2}{|c|}{ Number of specimens } & \multirow[b]{2}{*}{$\begin{array}{l}\text { Date of } \\
\text { collection }\end{array}$} & \multirow[b]{2}{*}{$\begin{array}{l}\text { Anaerobes } \\
\text { isolated }\end{array}$} \\
\hline & & taken & $\begin{array}{l}\text { positive for } \\
\text { anaerobes }\end{array}$ & & \\
\hline 1 & 17 & 17 & 6 & $\begin{array}{l}15 / 3 \\
10 / 3 \\
30 / 3 \\
18 / 5 \\
23 / 7 \\
14 / 8\end{array}$ & $\begin{array}{l}\text { B. intermedius } \\
\text { B. asaccharolyticus } \\
\text { Pigmented bacteroides* } \\
\text { B. intermedius } \\
\text { B. asaccharolyticus plus } \\
\text { anaerobic coccus } \\
\text { Pigmented bacteroides* }\end{array}$ \\
\hline 2 & 10 & 6 & 5 & $\begin{array}{l}12 / 6 \\
15 / 6 \\
17 / 6 \\
18 / 6 \\
13 / 7\end{array}$ & $\begin{array}{l}\text { B. disiens } \\
\text { B. disiens } \\
\text { B. disiens } \\
\text { B. disiens } \\
\text { B. disiens }\end{array}$ \\
\hline 3 & 7 & 5 & 2 & $\begin{array}{r}9 / 4 \\
13 / 4\end{array}$ & $\begin{array}{l}\text { Anaerobic coccus } \\
\text { Anaerobic coccus }\end{array}$ \\
\hline 4 & 11 & 14 & 5 & $\begin{array}{r}27 / 4 \\
18 / 5 \\
19 / 5 \\
3 / 8 \\
24 / 8\end{array}$ & $\begin{array}{l}\text { Anaerobic coccus } \\
B . \text { disiens } \\
\text { Veillonella } \\
\text { Anaerobic coccus } \\
B . \text { disiens }\end{array}$ \\
\hline 5 & 14 & 8 & 3 & $\begin{array}{r}14 / 7 \\
27 / 7 \\
7 / 9\end{array}$ & $\begin{array}{l}\text { Anaerobic coccus } \\
\text { Anaerobic coccus } \\
\text { B. ureolyticus }\end{array}$ \\
\hline
\end{tabular}

*Did not survive subculture.

culture to detect bacterial concentrations greater than $10^{5} \mathrm{cfu} / \mathrm{ml}$ of sputum. It is noteworthy that organisms growing in such concentrations were often detected after sonication and dilution only, suggesting either that they were sequestered deep within the viscid mucus produced by patients with $\mathrm{CF}$, or within the pus cells, and supporting the view that they were derived from the lungs rather than from the mouth.

Anaerobes were cultured from $23.85 \%$ of all processed specimens and at least once from nine of the 21 patients. The significance of this is difficult to determine, especially as only occasional specimens were taken from most patients. Anaerobes were isolated more than once from the sputum of five of the 10 patients from whom multiple specimens were taken. Different anaerobic species were isolated from three of the five on different occasions; it is, therefore, difficult to attribute much importance to these isolates. On the other hand, the same single Bacteroides spp. was isolated on five consecutive occasions from one patient, suggesting that this may have been clinically important.

The anaerobes isolated were, as expected, those likely to be found colonising the oropharynx and were broadly similar to those found in other studies of anaerobic pulmonary infection (Bartlett, 1987), in which pigmented Bacteroides spp. and anaerobic cocci are commonest. However, fusobacteria were common in other studies but none was found here. Similarly, B. fragilis was not isolated in this study, whereas in other studies, small but significant numbers have been found.

The pathogenic potential of anaerobes cannot be assessed from this study. Most of the antimicrobial drugs being taken by nearly all the patients when the specimens were collected would have had some activity against at least some of the anaerobes isolated, but whether this activity increases the patients' response to such chemotherapy is impossible to assess. However, the observation that anaerobes were isolated as often from patients attending clinic in a quiescent phase of the disease as from those admitted with acute exacerbations suggests a colonising rather than a pathogenic role. This, and the value of specific anti-anaerobe antibiotic treatment in $\mathrm{CF}$ require further investigation. 
We thank Dr C. J. Taylor and the staff at the Cystic Fibrosis clinic at Sheffield Children's Hospital for enabling us to obtain the sputum specimens, Mrs L. Goodwin for identifying the

\section{REFERENCES}

Bartlett J G 1987 Anaerobic bacterial infections of the lung. Chest 91 : 901-909.

Bartlett J G, Finegold S M 1974 Anaerobic infections of the lung and pleural space. American Reviews of Respiratory Disease 110: 56-77.

Bartlett J G, Finegold S M 1978 Bacteriology of expectorated sputum with quantitative culture and wash technique compared to transtracheal aspiration. American Reviews of Respiratory Disease 117: 1019-1027.

Bartlett J G, O'Keere P, Tally F P, Louie T J, Gorbach S L 1986 Bacteriology of hospital-acquired pneumonia. Archives of Internal Medicine 146: 868-871.

Brook I, Finegold S M 1980 Bacteriology of aspiration pneumonia in children. Pediatrics 65: 1115-1120.

Brook I, Fink R 1983 Transtracheal aspiration in pulmonary infection in children with cystic fibrosis. European Journal of Respiratory Disease 64: 51-57.

Duerden B I, Collee J G, Brown R, Deacon A G, Holbrook W P 1980 A scheme for the identification of clinical isolates of gram-negative anaerobic bacilli by conventional bacte-
Bacteroides spp. and Professor B. I. Duerden for advice in preparing the manuscript.

riological tests. Journal of Medical Microbiology 13: 231245.

Pollock H M, Hawkins E L, Bonner J R, Sparkman T, Bass J B 1983 Diagnosis of bacterial pulmonary infections with quantitative protected catheter cultures obtained during bronchoscopy. Journal of Clinical Microbiology 17: 255-259.

Ries K, Levison M E, Kaye D 1974 Transtracheal aspiration in pulmonary infection. Archives of Internal Medicine 133: 453-458.

Smith A L 1986 Antibiotic therapy in cystic fibrosis: evaluation of clinical trials. Journal of Pediatrics 108: 866-870.

Thomassen M J, Klinger J D, Badger S J, van Heeckeren D W, Stern R C 1984 Cultures of thoracotomy specimens confirm usefulness of sputum cultures in cystic fibrosis. Journal of Pediatrics 104: 352-356.

Winterbauer R H 1985 Diagnosis of bacterial pneumonia with fiberoptic bronchoscopy. European Journal of Clinical Microbiology 4: 95-97.

Winterbauer $\mathrm{R} \mathrm{H}$ et al. 1983 The use of quantitative cultures and antibody coating of bacteria to diagnose bacterial pneumonia by fiberoptic bronchoscopy. American Reviews of Respiratory Disease 128: 98-103. 